\title{
Corrigendum
}

\section{Secretion of a heat-stable fungal $\beta$-glucanase from transgenic, suspension-cultured barley cells}

Kristian Aspegren ${ }^{1, *}$, Leena Mannonen ${ }^{2}$, Anneli Ritala ${ }^{1,2}$, Riitta Puupponen-Pimiä ${ }^{2}$, Ulrika Kurtén $^{2}$, Marjatta Salmenkallio-Marttila ${ }^{2}$, Veli Kauppinen ${ }^{2}$ and Teemu H. Teeri ${ }^{1}$

${ }^{1}$ Institute of Biotechnology, P.O. Box 45, FIN-00014 University of Helsinki, Finland (*author for correspondence); ${ }^{2}$ VTT, Biotechnology and Food Research, P.O. Box 202, FIN-02151 Espoo, Finland

Molecular Breeding 1: 91-99, 1995.

In the above paper EGI, the heat-stable $\beta$-glucanase of Trichoderma reesei, is incorrectly referred to as a $(1 \rightarrow 3,1 \rightarrow 4)$ - $\beta$-glucanase by the authors. Wrong nomenclature appears three times in the article: in Key words on page 91, on the 9 th line from bottom on page 96 and on the 20th line from bottom on page 97. The correct reference for EGI's activity is $(1 \rightarrow 4)-\beta$-glucanase (EC 3.2.1.4). 